Scientific Review - Engineering and Environmental Sciences (2021), 30 (2), 221-235

Sci. Rev. Eng. Env. Sci. (2021), 30 (2)

Przegląd Naukowy - Inżynieria i Kształtowanie Środowiska (2021), 30 (2), 221-235

Prz. Nauk. Inż. Kszt. Środ. (2021), 30 (2)

http://iks.pn.sggw.pl

DOI 10.22630/PNIKS.2021.30.2.19

Alaa M. Al-LAMI, Yaseen K. Al-TIMIMI, Hasanain K.A. Al-SHAMARTI

Mustansiriyah University, College of Science

\title{
Spatiotemporal analysis of some extreme rainfall indices over Iraq (1981-2017)
}

Key words: extreme precipitation, RClimDex, ETCCDI, climate change, OLS, Iraq

\section{Introduction}

Global warming influences the global average increase in temperature which has a significant effect on regional precipitation by changing the thermodynamic properties of both sea and land (Lee, Lee \& Julien, 2018; Ding, Lu \& Wang, 2019). Regional and local flooding, droughts, and snowstorms caused by extreme weather conditions have environmental impacts on the progress of forests, animals, agriculture, and socio-economic (Knapp et al., 2008; Xiong et al., 2019). Precipitation is one of the most significant environmental factors for diagnosing climate change and may also determine the regionalscale eco-environmental approach to climate change (Subba, Ma \& Ma, 2019).

A great deal of research work has been done around the world to study extreme weather events based on some extreme indices. These extreme indices can be defined either based on the probability of occurrence of given quantities or according to threshold exceedances (Seneviratne, Pal, Eltahir \& Schär, 2002; Bartolomeu, Carvalho, Marta-Almeida, Melo-Gonçalves \& Rocha, 2018). The indices suggested by the Expert Team on Climate Change Detection Monitoring and Indices are commonly used (Parracho, Melo-Gonçalves \& Rocha, 2016). Globally, the fluctuations and trends of extreme precipitations have shown substantial spatial variation (Alexander et al., 2006; Li \& Hu, 2019). Asadieh and Krakauer (2015) study the patterns of global average precipitation. They noticed that $66.2 \%$ of their examined gridded points displayed a positive pattern in South America, Australia, and India over the past 110 years, $18 \%$ of which were statistically relevant at the $95 \%$ confidence levels (Asadieh \& Krakauer, 2015). Many studies from different re- 
gions indicated though, that extreme events in precipitation did not have the same regional continuity as extreme temperatures (Lovino, Garcia \& Baethgen, 2014; Tan, Ibrahim, Cracknell \& Yusop, 2017; Forestieri et al., 2018). Alexander et al. (2006) suggested that alterations in precipitation were significantly globally risen and prevalent. CMIP3 and CMIP5 model output suggested an increase in the global average of daily precipitation levels from about 6 to $7 \%$ over 20 -year period (Dai, 2006). Several researchers have also illustrated the important role of patterns of large-scale circulation in the optimistic pattern in rainfall anomaly events (Kenyon \& Hegerl, 2010). In the Middle East, several studies investigated extreme rainfall patterns (Balling, Keikhosravi, Kiany, Sen Roy \& Khoshhal, 2016; Gado, El-Hagrsy \& Rashwan, 2019; Tongal, 2019). Alijani, O'Brien and Yarnal (2008) noticed that about 20\% of the land area was at significant rainfall risk. The most intense heavy rainfall events were faced primarily by the warm, dry southern coast and the western slopes of the major north-south chain, the Zagros Mountains. Sensoy et al. (2013) show that there are strong consistent warming trends throughout Turkey impacting both high and minimum temperatures, but precipitation shifts are far more complex. Using long-term average rainfall data (1965-2015), Salman with research colleagues investigated the unidirectional patterns in rainfall and rainfall-related extremes in Iraq. The findings indicated that the region has suffered a long period of drought (Salman et al., 2018).

This research work aimed to study the behavior of extreme rainfall phenomena in Iraq. The proposed approach firstly divided the area of study into three distinguished regions. Then a spatiotemporal distribution of 10 extreme precipitation indices was analyzed for Iraq by using the daily data time series 1981-2017. The analyses were done using the RClimDex package and ArcMap 10.4 software.

\section{Material and methods}

\section{The study area and data source}

Iraq is located in the southwestern part of Asia, with an estimated area of $438,320 \mathrm{~km}^{2}$. It is surrounded by many countries, Turkey at the north, Iran in the eastern part, the southwestern part with Kuwait, and the Persian Gulf, and the southern part with Saudi Arabia. Also, it is located between the latitudes $37^{\circ} 22^{\prime} \mathrm{N}$ in the northern part with Turkey and $29^{\circ} 5^{\prime} \mathrm{N}$ in the southern part with Saudi Arabia, also, Iraq is located between the longitudes $38^{\circ} 45^{\prime} \mathrm{E}$, which bordered the Syrian desert and $48^{\circ} 45^{\prime} \mathrm{E}$ nearly to Shatt Al-Arab (Adeeb \& Al-Timimi, 2019; Al-Shamarti, Manji \& Albw Jbianah, 2019). The climate of Iraq is generally subtropical and semi-arid, except for the mountainous northern and northern east parts that have a Mediterranean climate. Most of the rainfall occurs between December and April, and the annual average ranges between 100 and $900 \mathrm{~mm}$. The mountainous region in northern Iraq has significantly more rainfall than the central and southern regions. Nearly $90 \%$ of the annual precipitation occurs between November and April. Annual average rainfall was measured at $216 \mathrm{~mm}$. Winters are mild and dry, with a daytime 
temperature falling to $2^{\circ} \mathrm{C}$ at night with a chance of frost. Summers are dry and hot to very hot, with shade temperatures reaching $43^{\circ} \mathrm{C}$ in July and August, but falling to $26^{\circ} \mathrm{C}$ in the winter (Al-Lami, Al-Timimi \& Al-Salihi, 2014). A dataset of daily rainfall of the period 1981 to 2017 for 36 meteorological stations was used in this study. This dataset was obtained from the official website of the NASA with a spatial resolution $\left(0.5^{\circ}\right.$ latitude $\times 0.5^{\circ}$ longitude). Figure 1 shows the geographical distribution of the selected station on the Iraq map.

The spatial distribution of rainfall is more realistic and accurate in mountainous terrain when elevation dependence is considered (Al-Ahmadi \& Al-Ahmadi, 2013; Song et al., 2019). Since the rainfall average varies from one region to another, the study area was divided into three regions depending on the k-mean method. Region 1 (northern) includes seven stations (Dukcan, Emadia, Sulaymaniyah, Salahaddin, Zakho, Duhook, and Erbil); Region 2 (middle) includes 10 stations (Sinjar, Mosul, Rabiah, Kirkuk, Tel-Afer, Khanaqin, Tuz, Baiji, Tikrit, and Samaraa); Region 3 (southern) includes 19 stations (Amara, Basrah, Anah, Kut, Qaim, Fao, Hai, Hadithah, Nasiriya, Heet, Ramadi, Baghdad, Rutba, Diwaniya, Hella, Samawa, Najaf, Kerbela, and Nukheb) - Figure 2. To test the suitability and accuracy of the study data, the RClimDex package in R software was used to submit all the rainfall data to a high-quality control. The quality control procedures included replacing the missing data with -99.99 , label negative data on the average precipitation as erroneous data, and checking the abnormality of selected data by considering all daily data that exceeding
FIGURE 1. The geographical location of grids corresponding to the stations in the study area (Iraq)

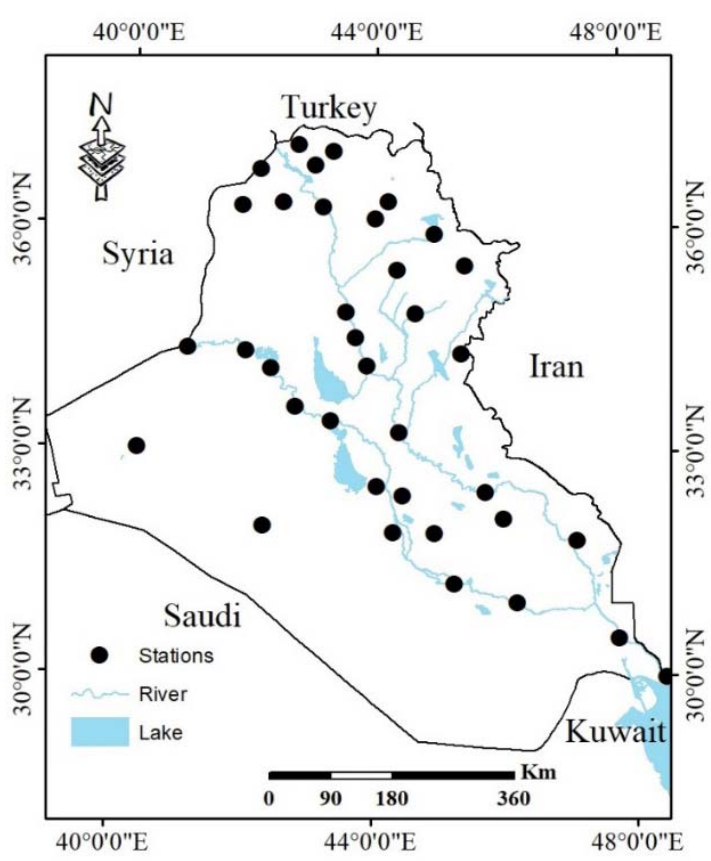




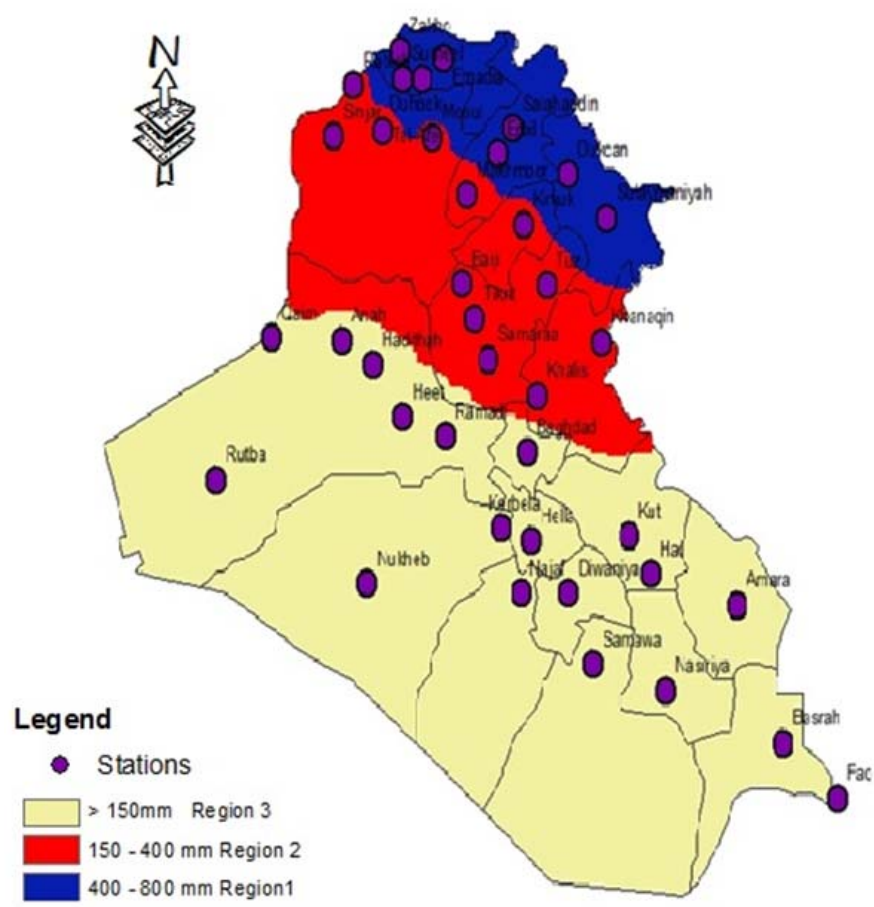

FIGURE 2. Classification of rainfall regions of the study area (Iraq)

the standard deviation for five times as (not available). An analysis of the visual data graphs was established to check the abnormal values. Abnormal values were omitted and adjusted based on statistical analyses and data from neighboring stations (Zhang \& Yang, 2004).

\section{Rainfall indices}

The extreme rainfall indices were calculated using RClimDex for the daily rainfall data of 36 meteorological stations in Iraq. This package is recommended by the Expert Team on Climate Change Detection and Indices (ETCCDI). The RClimDex has been developed by Zhang and Yang (2004). Providing easy-to-use software for estimating extreme climate indices. From the 27 indices established by the ETCCDI, 11 indices were assigned to determine indices of extreme rainfall. Ten indices are selected to quantify extreme rainfall events in Iraq, and these indices are widely used to study the spatiotemporal analysis of extreme rainfall. Ten indices were classified into two groups. The first one is rainfall days include (CDD, CWD, R10, and R20). The other group is rainfall total contain (PRCPTOT, SDII, R95, R99, RX1day, and RX5day). The table shows the specific details of these indices.

Trends of the rainfall indices were computed using the ordinary least square method (OLS). To determine the slope magnitude, the OLS used a linear model. Linear $p$-value trends of less than 0.10 were considered statistically significant in this study. 
TABLE. List of extreme precipitation indices, as adopted from (Dos Santos, de Brito, Júnior \& Dantas, 2012)

\begin{tabular}{|c|c|c|c|}
\hline Indices & ID & Name & Description \\
\hline \multirow{6}{*}{$\begin{array}{l}\text { Rainfall } \\
\text { total } \\
{[\mathrm{mm}]}\end{array}$} & PRCPTOT & Annual total wet day rainfall & Annual total from days $\geq 1 \mathrm{~mm}$ rainfal \\
\hline & SDII & Simple daily intensity index & Ratio of annual total to WD in a year \\
\hline & R95p & Very wet days & $\begin{array}{l}\text { Annual total rainfall of days in } \\
\quad>95^{\text {th }} \text { percentile }\end{array}$ \\
\hline & R99p & Extremely wet days & $\begin{array}{c}\text { Annual rainfall of days in }>99^{\text {th }} \text { per- } \\
\text { centile }\end{array}$ \\
\hline & RX1day & Max 1-day rainfall amount & Annual maximum 1-day rainfall \\
\hline & RX5day & Max 5-day rainfall amount & $\begin{array}{l}\text { Annual maximum consecutive 5-day } \\
\text { rainfall }\end{array}$ \\
\hline \multirow{4}{*}{$\begin{array}{l}\text { Rainfall } \\
\text { days } \\
{[\mathrm{mm}]}\end{array}$} & CDD & Consecutive dry days & $\begin{array}{c}\text { Maximum number of consecutive dry } \\
\text { days } \\
\text { (rainfall of }<1 \mathrm{~mm} \text { ) }\end{array}$ \\
\hline & CWD & Consecutive wet days & $\begin{array}{c}\text { Maximum number of consecutive wet } \\
\text { days } \\
\text { (rainfall of } \geq 1 \mathrm{~mm} \text { ) }\end{array}$ \\
\hline & $\mathrm{R} 10 \mathrm{~mm}$ & Number of heavy rainfall days & $\begin{array}{l}\text { Annual count of days when rainfall is } \\
\qquad \geq 10 \mathrm{~mm}\end{array}$ \\
\hline & $\mathrm{R} 20 \mathrm{~mm}$ & Number of very heavy rainfall days & $\begin{array}{l}\text { Annual count of days when rainfall is } \\
\qquad \geq 20 \mathrm{~mm}\end{array}$ \\
\hline
\end{tabular}

\section{Results and discussion}

\section{Temporal analysis of extreme rainfall indices}

Depending on the rainfall values of all the considered stations and by using the k-mean algorithm, the study area was divided into three regions, northern, middle, and southern from 1981 to 2017 . The annual time series of ten extreme rainfall indices in the study regions (northern, middle, and southern Iraq) are shown in Figures 3-8. In Figures 3 and 4, the rainfall indices in the northern region of Iraq showed an increasing trend during 1981-2017. A significant increase trend was distinguished for PRCPTOT with a rate of change of $2.625 \mathrm{~mm}$ per year. This is due to the effects of low-pressure system which cause a high intensity of rainfall especially in the northern regions of Iraq. The trends of SDII significantly increased with a change rate of $0.038 \mathrm{~mm}$ per day per year. The regional values of RX1day and RX5day were similar, and the rate of positive trend 0.348 and $0.722 \mathrm{~mm}$ per year, respectively. R95p and R99p showed a high value of slope with a rate of 2.54 and $1.38 \mathrm{~mm}$ per day, respectively. Regarding rainfall days indices in this northern region, CDD and R10 showed a significant increase in the trend with a rate of change of 0.87 and 0.14 when compared to the trend of SDII 



FIGURE 3. Temporal variations for the northern region of extreme rainfall total indices: a - PRCPTOT; b - SDII; c - RX1day; d-RX5day; e - R95; f - R99 respectively. The solid grey line is the linear trend, the solid black line is the annual variations and the dotted black line is the five-year smoothing average
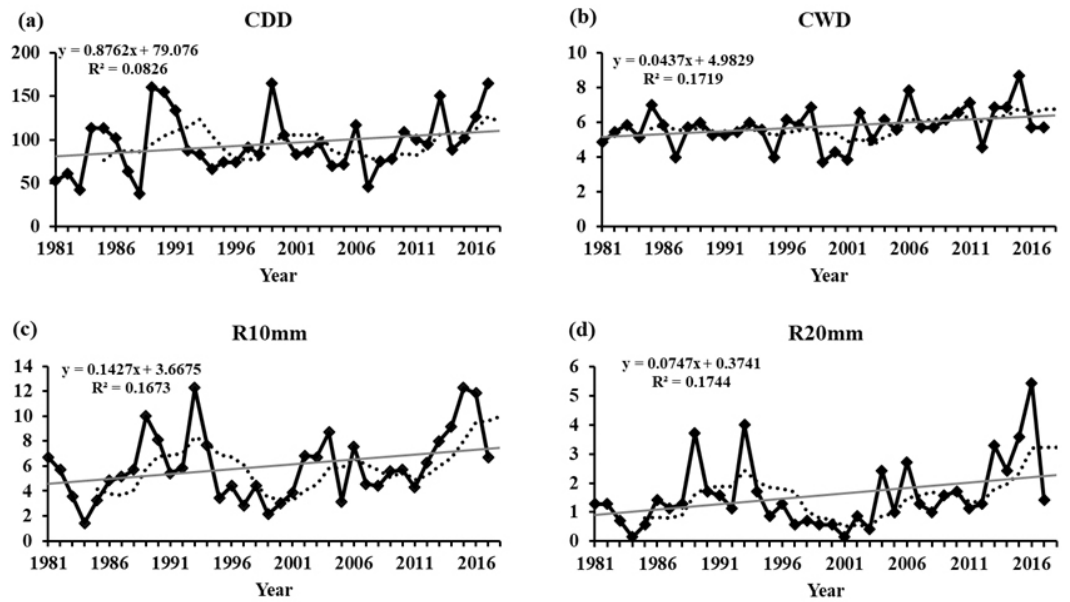

FIGURE 4. Temporal variations for the northern region of extreme rainfall days indices: a - CDD; $\mathrm{b}-\mathrm{CWD}$; $-\mathrm{R} 10 ; \mathrm{d}-\mathrm{R} 20$ respectively. The solid grey line is the linear trend, the solid black line is the annual variations and the dotted black line is the five-year smoothing average 
and R20. All indices showed a significant increase during the last 10 years. The reason for this significant increase could be due to the El Niño-Southern Oscillation (ENSO) cold (La Niña) phases in various parts of the world and its impact on the climatic events on these regions. Additionally, the five years moving average slope showed that there were three-clear peaks for most indices that occurred during 2015, 2006, and 1993. The result of the temporal distribution for the ten indices on the surrounding countries like Iran, Turkey and also in China showed an upward trend for all these indices
(Sensoy et al., 2013; Balling et al., 2016; Ding et al., 2019).

Figures 5 and 6 illustrate the middle region (Region 2). It can be seen that this region has a positive trend that appeared for all indices. Precipitation total indices showed a high increase in PRCPTOT and R95p with a change rate of $3.26 \mathrm{~mm}$ per day per year and $1.61 \mathrm{~mm}$ per year, respectively. A low rate of change was noted for other indices, especially in SDII and RX1day. There was no significant increase in the trend in rainfall days' indices, except a high trend that appeared in CDD 0.5 days.
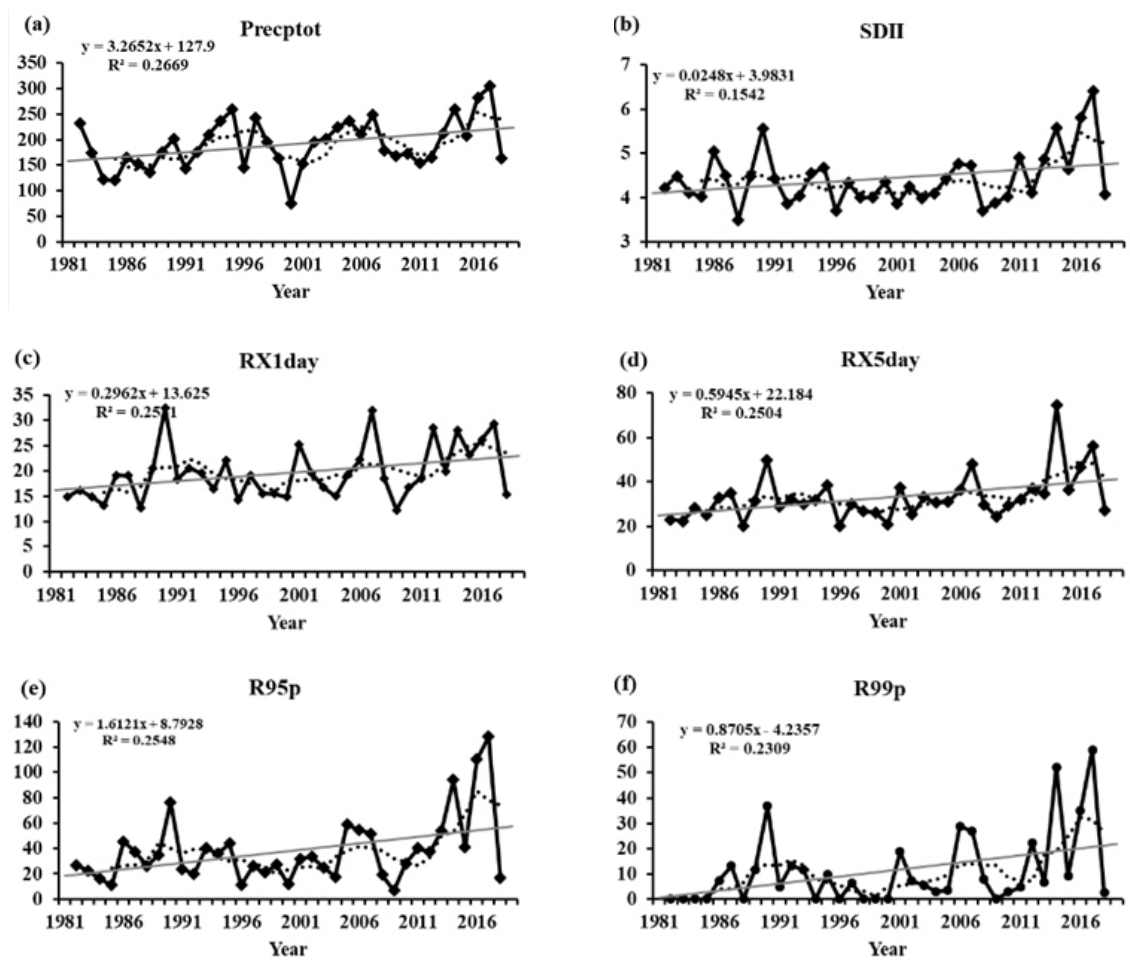

FIGURE 5. Temporal variations for the middle region of extreme rainfall total indices: a - PRCPTOT; $\mathrm{b}-\mathrm{SDII}$; $\mathrm{c}-\mathrm{RX1day}$; $\mathrm{d}-\mathrm{RX} 5$ day; e - R95; f - R99 respectively. The solid grey line is the linear trend, the solid black line is the annual variations and the dotted black line is the five-year smoothing average 


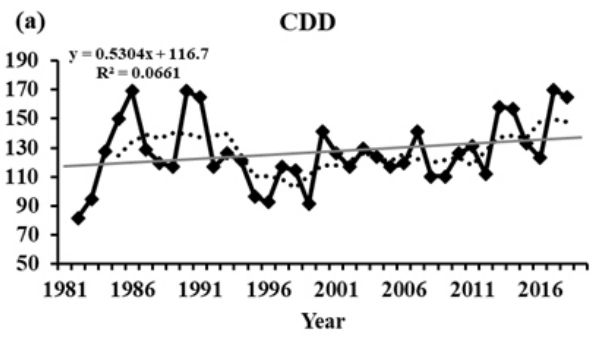

(b)

CWD
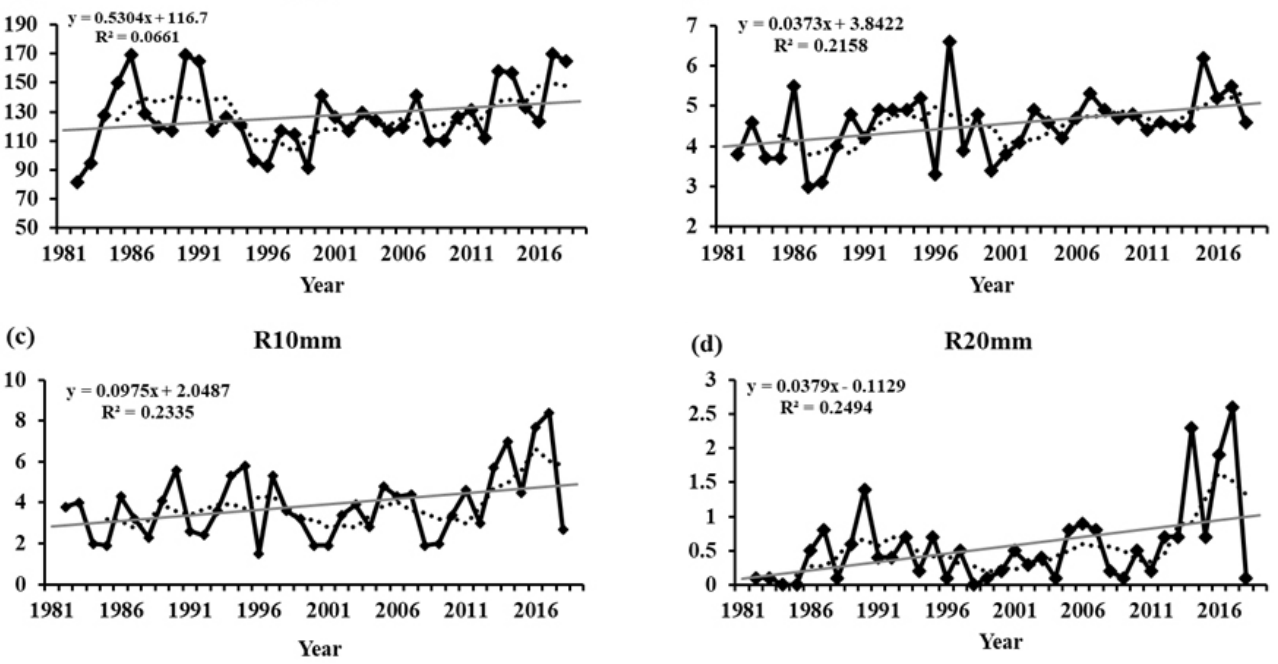

(d)

R20mm

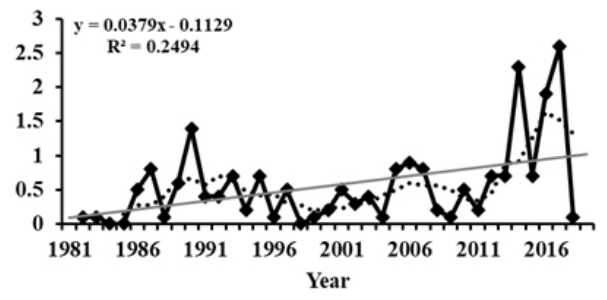

FIGURE 6. Temporal variations for the middle region of extreme rainfall days indices: a - CDD; $\mathrm{b}-\mathrm{CWD}$; $\mathrm{c}-\mathrm{R} 10 ; \mathrm{d}-\mathrm{R} 20$ respectively. The solid grey line is the linear trend, the solid black line is the annual variations and the dotted black line is the five-year smoothing average
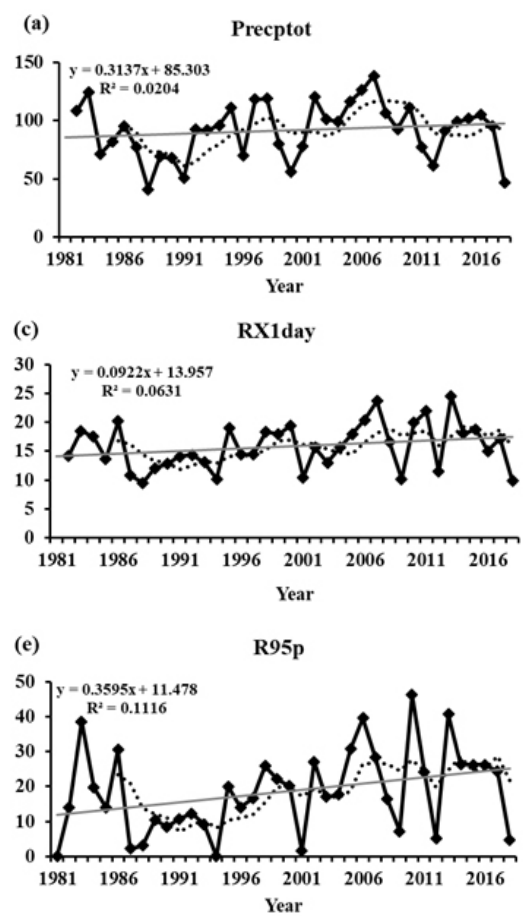
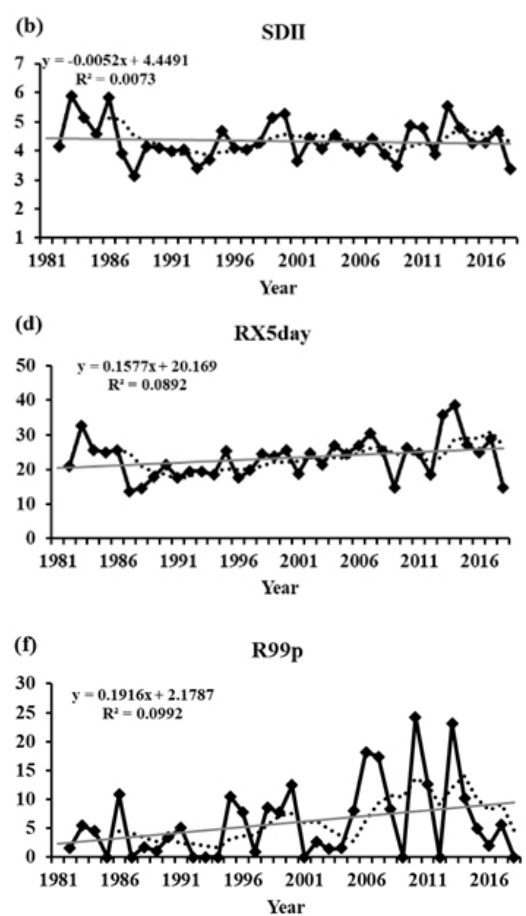

FIGURE 7. Temporal variations for the southern region of extreme rainfall total indices: a - PRCPTOT; $\mathrm{b}$ - SDII; c-RX1day; d-RX5day; e-R95; f-R99 respectively. The solid grey line is the linear trend, the solid black line is the annual variations and the dotted black line is the five-year smoothing average 
(a)

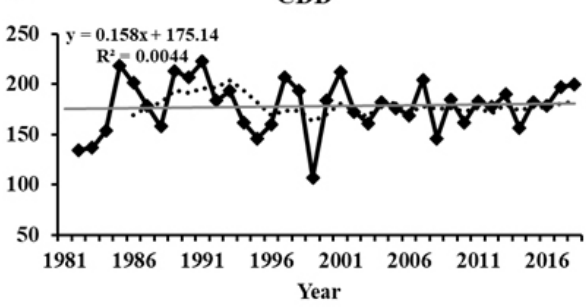

(c)

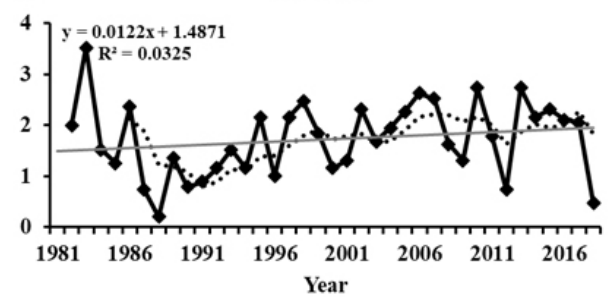

(b)

CWD

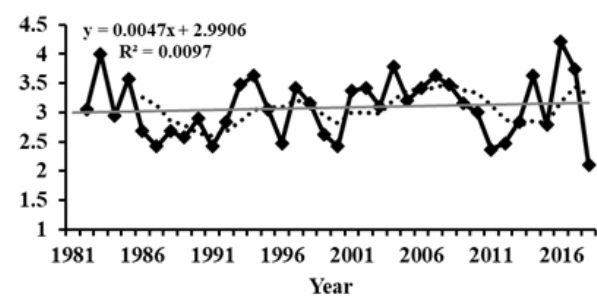

(d)

R20mm

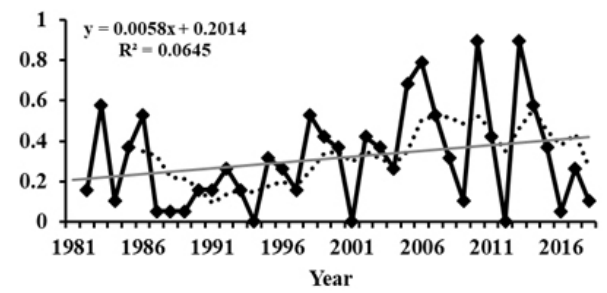

FIGURE 8. Temporal variations for the southern region of extreme rainfall days indices: a - CDD; $\mathrm{b}-\mathrm{CWD}$; $\mathrm{c}-\mathrm{R} 10 ; \mathrm{d}-\mathrm{R} 20$ respectively. The solid grey line is the linear trend, the solid black line is the annual variations and the dotted black line is the five-year smoothing average

Figures 7 and 8 illustrate Region 3 which represents the southern parts of Iraq, where only SDII showed a negative trend with a rate of $-0.0052 \mathrm{~mm}$ per year. Other indices showed a less increase in the trend compared to that of the middle and northern regions. Spatial analysis indicated that most western and southerner stations included in this region showed a negative trend for most indices which led to low values of trend increasing in the third region.

\section{Spatial analysis of extreme rainfall indices}

Ten rainfall indices were divided into two groups, the first group was (PRCPTOT, SDII, R95, R99, RX1day, and RX5day), and the second group of indices (CDD, CWD, R10, and R20). The spatial distribution of rainfall total indices during 1981-2017 is shown in Figure 9. The high PRCPTOT value occurred mainly in the northwestern region of Iraq, and the low values were distributed primarily in the southwestern regions. The values of PRCPTOT fluctuated between $45.6 \mathrm{~mm}$ per year, which appeared in Nukheb station, and $357 \mathrm{~mm}$ per year in Zakho station.

Herein $39 \%$ of stations showed PRCPTOT values less than $100 \mathrm{~mm}$ per year, $22 \%$ of stations showed a negative trend of PRCPTOT, and these stations were distributed primarily in the western parts of Iraq, except Basra and Fao stations, in the south of Iraq. A higher positive trend value appeared in Tuz, Khanqinand, and Zakho (4.6, 4.55, and $4.04 \mathrm{~mm}$ per year, respectively). The spatial distribution of this index revealed that the wetter region was in northwestern Iraq. Significantly high values of SDII appeared generally in the northern and eastern regions of Iraq, and 

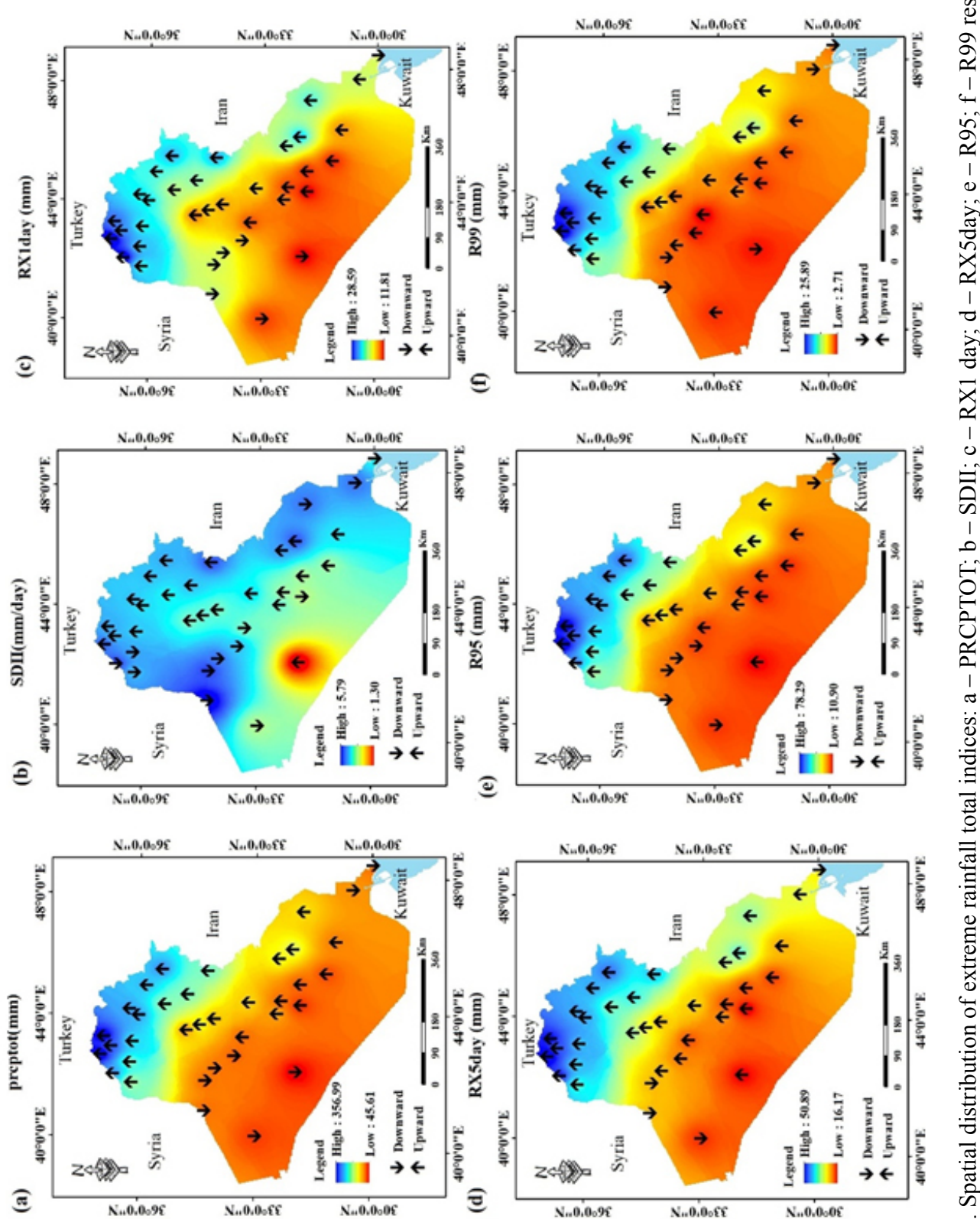

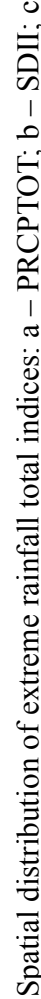

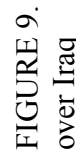


approximately $79 \%$ of SDII values were more than $4 \mathrm{~mm}$ per day per year. A lower SDII value was recorded at Nukheb in the southeastern of Iraq (1.2 mm per day per year), because this site represents the most drier site in Iraq according to records of the total rainfall in this station. A percent of $36 \%$ of the stations revealed a negative SDII value, the lowest significant trend was at Qaim -0.054 and the highest trend appeared in Kirkuk 0.067. The values of RX1day and RX5day also indicated a similar distribution, and the highest values of these indices appeared mainly in the stations lies north $36^{\circ}$ latitude, while the lowest value was at the western parts of Iraq. Additionally, Najaf station indicated a low value of both indices 11.8 and $16.6 \mathrm{~mm}$ per year, respectively. A negative trend appeared in $19.4 \%$ of RX1day and $11 \%$ of RX5day. Anah and Qaim displayed a significant negative trend for both indices -0.19 and -0.14 . The indices of very wet days R95p and extremely wet days R99p ranged from $10.9-78.3$ to $2.7-25.9 \mathrm{~mm}$ per year, respectively. However, both indices in the northwest part of Iraq were more extreme. The pattern of R95p and R99p distribution also showed similarity, where the lowest value appeared in the western part of Iraq chiefly in Heet, Najaf, and Rutba, but the highest values appeared in both Zakho and Emadiyah. A negative trend indicated only in $11.4 \%$ of stations. According to RX1day and RX5day, only five stations showed a negative trend (Anah, Basrah, Fao, Nukheb, and Qaim). Significant positive trends for both indices were indicated in Sulaymaniyah and Dukan. Concerning the above six indices, northern and eastern parts of Iraq showed positive trends with a high probability of extreme rainfall in these regions. The cause can be attributed to the elevation influence of increased relief amplitude on airflow variability, and the elevation of topography has caused the northern parts of Iraq to rainfall more than other regions. Conversely, the low trend appeared mainly in the western and southern parts of Iraq. Another reason for trending in extreme rainfall in this area could be the event ENSO. Recent ENSO studies have established a significant climatic correlation between the anomaly of rainfall and both the Southern Oscillation warm (El Niño) and cold (La Niña) phases in various parts of the world (Ding et al., 2019; Xiong et al., 2019). Regarding the spatial analysis of extreme rainfall days (Fig. 10). The CDD values exhibited a significant increase from the northwestern to the southwestern of Iraq, between 66 days at Samara and 197 days at Najaf. Seventy eight percent of the stations revealed a positive trend, however, only six stations have significant trends increasing, and most of them were distributed in the northern. Samawah and Samara showed low values of CDD due to the extremely low values of rainfall intensity in these two stations. In contrast, the CWD index spatial trend ranged between 2.1 and 6.7 days per year. The largest concentration of CWD was maintained in the northwest of Iraq. The peak values of CWD were recorded in two stations Emadiayia and Zakho (6.7 and 6.6 days, respectively). The concentration was found to increase with the rise in elevation for the northwestern part of Iraq (Al-Ahmadi \& Al-Ahmadi 2013; Song et al., 2019). Only four stations showed negative trends 

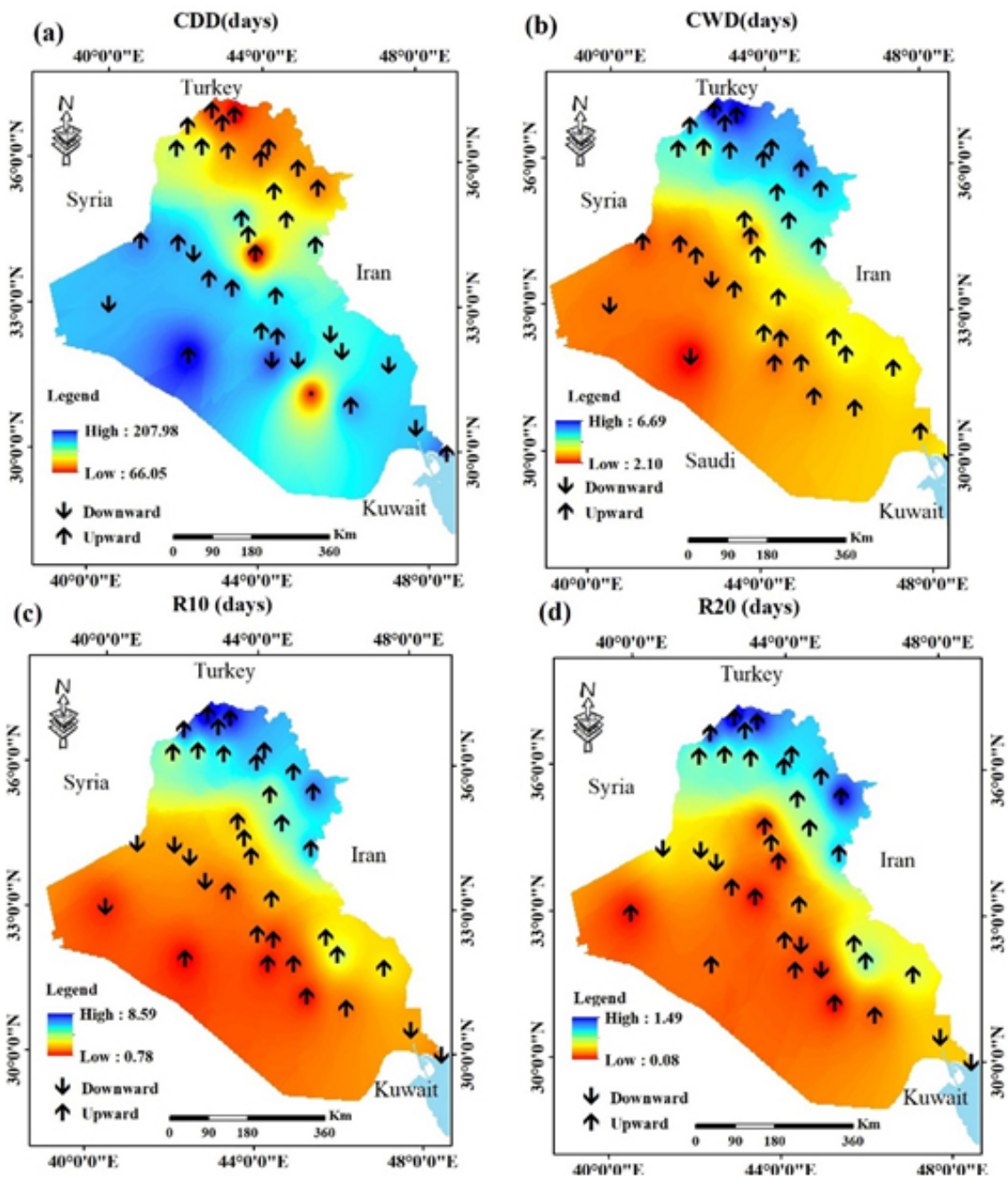

FIGURE 10. Spatial distribution of extreme rainfall days indices: $a-C D D ; b-C W D ; c-R 10 ; d-R 20$ respectively over Iraq

(Nukheb, Heet, Rutba, and Fao), most of them in the western part of Iraq, except Fao (Fig. 10).

The frequency of annual rainfall day level $(\mathrm{R} 10 \mathrm{~mm})$ index ranged from 0.78 to 8.6 days per year. This index's spatial distribution was close to that of the CWD index, although its higher concentration in northwestern of Iraq. Figure 10 also showed that R10 and R20 values were similar and increased values appeared in the northern parts of Iraq (Hassan, Zeki \& Salih, 2018; Al-Nassar, Pelegri, Sangrà, Alarcon \& Jansa, 2020). Seven stations for both indices showed a negative trend, most of them dispersed in the west of Iraq. Additionally, all stations showed a non-significant trend increasing, 
however, a maximum trend was noted at Khanqin for both indices $(0.17$ and 0.07 days, respectively).

\section{Conclusions}

In this study, we used daily rainfall data from 36 meteorological stations in Iraq to examine the spatiotemporal distribution of extreme rainfall indices using RClimDex package. Ten indices were chosen and divided into two classes: rainfall total (PRCPTOT, SDII, R95, R99, RX1day, and RX5day) and precipitation days (CDD, CWD, R10, and R20). The area of the study was divided into three regions to investigate the temporal characteristics of the time series for extreme rainfall indices. This study came out with several conclusions:

1. High values of rainfall total indices appeared in the northwestern part of Iraq, whereas the lowest values of these indices appeared in western and southern regions. Most of the stations revealed positive trends except seven stations in the western and southern parts of Iraq (Heet, Haditha, Anah, Rutba, Qaim, Nukheb, Fao), which showed a negative trend.

2. Results of rainfall days revealed higher values of consecutive dry days (CDDs) in Najaf and Nukheb stations. Higher values of other indices CWD, R10, R20 appeared mostly at Zakho and Emadiyah in the northern parts of Iraq. The positive trend was non-significant for most rainfall days indices.

3. A high probability of extreme rainfall in the northern and eastern parts of Iraq.
4. Time series analysis of extreme rainfall indices showed a positive increase in the regions under study, except one negative trend appeared in SDII for Region 3. A high rate of change appeared in the north of Iraq, especially for PRCPTOT, R95, and CDD.

5. All indices showed a significant increase during the last 10 years.

6. According to the results of the study we suggest that the Iraqi government needs to take quick actions like designing a national water master plan and implement regional cooperation and coordination.

\section{Acknowledgements}

The authors are grateful to the National Aeronautics and Space Administration (NASA) Goddard Earth Sciences Data Information and Services for the provision of the data used in this study.

\section{References}

Adeeb, H.Q. \& Al-Timimi, Y.K. (2019). GIS techniques for mapping of wind speed over Iraq. Iraqi Journal of Agricultural Sciences, 50(6), 1621-1629.

Al-Ahmadi, K. \& Al-Ahmadi, S. (2013). Rainfall-altitude relationship in Saudi Arabia. Advances in Meteorology, 2013, 363029. https://doi.org/10.1155/2013/363029

Alexander, L.V., Zhang, X., Peterson, T.C., Caesar, J., Gleason, B., Klein Tank, A.M.G., Haylock, M., Collins, D., Trewin, B., Rahimzadeh, F., Tagipour, A., Rupa Kumar, K., Revadekar, J., Griffiths, G., Vincent, L., Stephenson, D.B., Burn, Aguilar, E., Brunet, M., Taylor, M., New, M., Zhai, P., Rusticucci, M. \& Vazquez-Aguirre, J.L. (2006). Global observed changes in daily climate extremes of temperature and precipitation. Journal 
of Geophysical Research: Atmospheres, 111(D5), 1-22.

Alijani, B., O'Brien, J. \& Yarnal, B. (2008). Spatial analysis of precipitation intensity and concentration in Iran. Theoretical and Applied Climatology, 94(1), 107-124.

Al-Lami, A.M., Al-Timimi, Y.K. \& Al-Salihi, A.M. (2014). The homogeneity analysis of rainfall time series for selected meteorological stations in Iraq. Diyala Journal for Pure Science, 10(2), 60-77.

Al-Nassar, A.R., Pelegrí, J.L., Sangrà, P., Alarcon, M. \& Jansa, A. (2020). Cut-off low systems over Iraq: Contribution to annual precipitation and synoptic analysis of extreme events. International Journal of Climatology, 40(2), 908-926.

Al-Shamarti, H.K., Manji, O.B. \& Albw Jbianah, M.I.K. (2019). Using monthly rainfall data to estimate rainfall erosivity factor of Iraq. Scientific Review Engineering and Environmental Sciences, 28(3), 444-454.

Asadieh, B. \& Krakauer, N.Y. (2015). Global trends in extreme precipitation: climate models versus observations. Hydrology and Earth System Sciences, 19(2), 877-891.

Balling, R.C., Keikhosravi Kiany, M.S., Sen Roy, S. \& Khoshhal, J. (2016). Trends in extreme precipitation indices in Iran: 1951-2007. Advances in Meteorology, 2016, 2456809. https://doi.org/10.1155/2016/2456809

Bartolomeu, S., Carvalho, M.J., Marta-Almeida, M., Melo-Gonçalves, P. \& Rocha, A. (2016). Recent trends of extreme precipitation indices in the Iberian Peninsula using observations and WRF model results. Physics and Chemistry of the Earth, Parts $A / B / C, 94,10-21$.

Dai, A. (2006). Recent climatology, variability, and trends in global surface humidity. Journal of Climate, 19(15), 3589-3606.

Ding, Z., Lu, R. \& Wang, Y. (2019). Spatiotemporal variations in extreme precipitation and their potential driving factors in non-monsoon regions of China during 1961-2017. Environmental Research Letters, 14(2), 024005. https://doi.org/10.1088/1748-9326/aaf2ec

Dos Santos, C.A.C., Brito, J.I., de, Júnior, C.H.D.S. \& Dantas, L.G. (2012). Trends in precipitation extremes over the northern part of Brazil from Era40 dataset. Revista Brasileira de Geografia Física, 5(4), 836-851.
Forestieri, A., Arnone, E., Blenkinsop, S., Candela, A., Fowler, H. \& Noto, L.V. (2018). The impact of climate change on extreme precipitation in Sicily, Italy. Hydrological Processes, 32(3), 332-348.

Gado, T.A., El-Hagrsy, R.M. \& Rashwan, I.M.H. (2019). Spatial and temporal rainfall changes in Egypt. Environmental Science and Pollution Research, 26(27), 28228-28242.

Hassan, A.S., Zeki, K.N. \& Salih, N.S. (2018). Determination the quantity of extreme rainfall and calculation of the climatology mean for Baghdad City. Iraqi Journal of Science, 95(1B), 447-455.

Kenyon, J. \& Hegerl, G.C. (2008). Influence of modes of climate variability on global temperature extremes. Journal of Climate, 21(15), 3872-3889.

Knapp, A.K., Beier, C., Briske, D.D., Classen, A.T., Luo, Y., Reichstein, M., Smith, M.D. \& Weng, E. (2008). Consequences of more extreme precipitation regimes for terrestrial ecosystems. Bioscience, 58(9), 811-821.

Lee, J.H., Lee, J.H. \& Julien, P.Y. (2018). Global climate teleconnection with rainfall erosivity in South Korea. Catena, 167, 28-43.

Li, X. \& Hu, Q. (2019). Spatiotemporal changes in extreme precipitation and its dependence on topography over the Poyang Lake Basin, China. Advances in Meteorology, 2019, 253932. https://doi.org/10.1155/2019/1253932

Lovino, M., García, N.O. \& Baethgen, W. (2014). Spatiotemporal analysis of extreme precipitation events in the Northeast region of Argentina (NEA). Journal of Hydrology: Regional Studies, 2, 140-158.

Parracho, A.C., Melo-Gonçalves, P. \& Rocha, A. (2016). Regionalisation of precipitation for the Iberian Peninsula and climate change. Physics and Chemistry of the Earth, Parts A/B/C, 94, 146-154.

Salman, S.A., Shahid, S., Ismail, T., Rahman, N.B.A., Wang, X. \& Chung, E.S. (2018). Unidirectional trends in daily rainfall extremes of Iraq. Theoretical and Applied Climatology, 134(3), 1165-1177.

Seneviratne, S., Pal, J., Eltahir, E. \& Schär, C. (2002). Summer dryness in a warmer climate: a process study with a regional climate model. Climate Dynamics, 20(1), 69-85. 
Sensoy, S., Türkoğlu, N., Akçakaya, A., Ekici, M., Demircan, M., Ulupinar, Y., Atay, H., Tüvan, A. \& Demirbaş, H. (2013). Trends in Turkey climate indices from 1960 to 2010 . In 6th International Atmospheric Science Symposium - ATMOS2013. Book of Proceedings. Istanbul: Istanbul Technical University. Retrieved from http://212.174.109.9/ FILES/genel/makale/19_trendsin-turkey. pdf [access 24.06.2020].

Song, L., Chen, M., Gao, F., Cheng, C., Chen, M., Yang, L. \& Wang, Y. (2019). Elevation influence on rainfall and a parameterization algorithm in the Beijing area. Journal of Meteorological Research, 33(6), 1143-1156.

Subba, S., Ma, Y. \& Ma, W. (2019). Spatial and temporal analysis of precipitation extremities of Eastern Nepal in the last two decades (1997-2016). Journal of Geophysical Research: Atmospheres, 124(14), 7523-7539.

Tan, M.L., Ibrahim, A.L., Cracknell, A.P. \& Yusop, Z. (2017). Changes in precipitation extremes over the Kelantan River Basin, Malaysia. International Journal of Climatology, 37(10), 3780-3797.

Tongal, H. (2019). Spatiotemporal analysis of precipitation and extreme indices in the Antalya Basin, Turkey. Theoretical and Applied Climatology, 138(3), 1735-1754.

Xiong, J., Yong, Z., Wang, Z., Cheng, W., Li, Y., Zhang, H., Ye, Ch. \& Yang, Y. (2019). Spatial and temporal patterns of the extreme precipitation across the Tibetan Plateau (1986-2015). Water, 11(7), 1453. https://doi. org/10.3390/w11071453

Zhang, X. \& Yang, F. (2004). RClimDex (1.0). User Manual. Ottawa (ON): Climate Research Branch Environment Canada.

\section{Summary}

Spatiotemporal analysis of some extreme rainfall indices over Iraq (1981-2017). Extreme rainfall is one of the environmental hazards with disastrous effects on the human environment. Water resources management is very vulnerable to any changes in rainfall intensities. A spatiotemporal analysis is essential for study the impact of climate change and variability on extreme rainfall. In this study, daily rainfall data for 36 meteorological stations in Iraq during 1981-2017 were used to investigate the spatiotemporal pattern of 10 extreme rainfall indices using RClimDex package. These indices were classified into two categories: rainfall total (PRCPTOT, SDII, R95p, R99p, RX1day, and RX5day) and rainfall days (CDD, CWD, R10, and R20). Depending on the mean annual precipitation data, the study area was divided into three climatic zones to examine the time series features of those 10 indices. Results showed a tendency to increase in precipitation toward the northwestern part of Iraq, and more than $70 \%$ of stations achieved a positive trend for most indices. The most frequent negative trend appeared in eight stations distributed in the western and southern parts of Iraq, namely (Heet, Haditha, Anah, Rutba, Qaim, Nukheb, Najaf, and Fao). A significant positive trend appeared obviously in PRCPTOT and R95p with a rate of 0.1-4.6 and $0.5-2.7 \mathrm{~mm}$ per year, respectively. Additionally, the least trend increasing appeared in all precipitation days indices specifically in R10 and R20. Time series analyses revealed a positive trend in all regions under study, except SDII in the southern region. The most significant rate of change was noticed in regions one and two (northern and middle parts of Iraq), particularly for PRCPTOT and R95p 3.26 and $2.45 \mathrm{~mm}$ per day, respectively. Only the northern and eastern regions of Iraq experienced a high probability of significant extreme rainfall.

\section{Authors' address:}

Alaa M. Al-Lami - corresponding author (https://orcid.org/0000-0003-0641-5015) Mustansiriyah University

College of Science

Department of Atmospheric Sciences

Palestine Street, 46131 Baghdad

Iraq

e-mail: al.shayia.atmsc@uomustansiriyah.edu.iq 